\title{
Entrevista com Pedro Santinho: uma história de luta em uma fábrica sob o comando dos trabalhadores
}

\author{
Beatriz Ferraz Diniz $z^{2}$ \\ Instituto de Psicologia da Universidade de São Paulo
}

$\mathrm{D}$

a cinco do mês de março de 2008. Ocorreu na cidade de Sumaré, em São Paulo, uma audiência pública com o objetivo de discutir a situação da Flaskô, uma fábrica da cidade. Mais precisamente, discutiram medidas viáveis para que ela continue funcionando. Estavam presentes inúmeros trabalhadores, sentados ao fundo da Câmara Municipal, juntamente com representantes de diversos movimentos sociais e de partidos políticos, além de alguns vereadores. A cena mostra claramente que não se trata de uma audiência comum e, tampouco, de uma fábrica comum.

Compondo a mesa da audiência estava o entrevistado desta edição: Pedro Santinho, coordenador do conselho de fábrica da Flaskô. Com formação em administração de empresas e em ciências sociais, ele auxilia na administração e na coordenação de diversas instâncias de decisão da fábrica. Anteriormente desempregado, aproximou-se da Flaskô por conta de seu trabalho de organização junto com os trabalhadores das fábricas Cipla e Interfibra, indústrias de material de construção de Joinville, Santa Catarina.

Para falar da Flaskô "sob o comando dos trabalhadores" é preciso ter em conta o surgimento, recente na história do Brasil, do Movimento das Fábricas Ocupadas, nascido junto com as ocupações na Cipla e na Interfibra. Atualmente, somente a Flaskô e a Álcalis, no Rio de Janeiro, permanecem ocupadas.

A Flaskô é uma fábrica do setor químico-plástico, localizada no Parque dos Bandeirantes, em Sumaré, que foi ocupada em doze de junho de 2003, por cerca de noventa trabalhadores. Como nos diz Pedro - "sabíamos que a fábrica era viável, mas que tinha sido prejudicada por uma série de fatores da época do dono. Isso foi um elemento que permitiu aos trabalhadores lutarem por seus empregos de uma maneira coletiva, ocupando a fábrica (...)”.

O objetivo da entrevista, realizada na própria fábrica, em dezembro de 2007, foi conhecer o que os trabalhadores da empresa denominam de "gestão operária". Algumas questões motivaram a realização da entrevista, como, por exemplo: como é viver e trabalhar numa fábrica ocupada? Aliás, o que constitui uma fábrica ocupada? O entrevistado sugere alguns caminhos para as respostas contando o processo de ocupação da fábrica e os desafios enfrentados diariamente.

Ainda que o contato com os trabalhadores tenha sido breve, pude perceber um ambiente diferenciado do ponto de vista das relações de trabalho, em que a liberdade de expressão parece se fazer presente. Nesse contato, também pareceu que a luta desses

1 Trabalho realizado sob orientação da professora Leny Sato do Instituto de Psicologia da Universidade de São Paulo. Agradeçemos ao Thiago de Oliveira e ao Fábio de Oliveira pelas sugestões para o aprimoramento deste trabalho.

2 Estudante de psicologia do Instituto de Psicologia da Universidade de São Paulo. Contato: biafdn@gmail.com 
trabalhadores em manter a fábrica funcionando não se restringe à busca por manter uma fonte de renda, mas se constitui numa iniciativa em tomar em suas mãos, de forma autônoma, o poder de direcionar suas próprias vidas.

Por fim, gostaria de agradecer a Pedro Santinho e aos demais trabalhadores da Flaskô por possibilitarem que eu conhecesse essa experiência.

\section{"Eu faço a parte administrativa, mas não sozinho..."}

\section{Beatriz - Q ual é o seu cargo na Flaskô?}

Pedro - Eu trabalho na área administrativa, em um cargo eletivo. Fui eleito como coordenador do conselho da fábrica e coordenador administrativo.

Beatriz - Como é sua historia na Flaskô?

Pedro - Eu fui contratado formalmente para trabalhar na Flaskô depois que a fábrica foi ocupada pelos trabalhadores. Eu, nesta época, apoiava a luta dos trabalhadores da Cipla e da Interfibra ${ }^{3}$, em Santa Catarina, fábricas que então se encontravam ocupadas. A gente fazia campanha no movimento estudantil, principalmente aqui na Unicamp, e no movimento sindical, em defesa da ocupação das fábricas em Santa Catarina. Aqui eu ajudei a organizar e preparar as reuniões e as assembléias que precederam a ocupação da Flaskô. Eu não era contratado pela fábrica, os trabalhadores não podiam tomar essa decisão. Naquela época eu tinha acabado de sair do meu emprego anterior e os meus gastos eram sustentados pela comissão de fábrica.

Beatriz - Qual era o seu emprego anterior?

Pedro - Eu fui funcionário publico do Conselho Regional de Engenharia, era auxiliar administrativo. Assim que a fábrica foi ocupada, em 12 de junho de 2003, eu fui imediatamente contratado, mas naquela época eu não ocupava o cargo que eu ocupo hoje.

Beatriz - Então, inicialmente, qual era sua ocupação na Flaskô?

Pedro - Eu tive vários cargos na verdade dentro da fábrica. No começo, fui contratado com o objetivo bastante preciso de ajudar a organizar a mobilização da fábrica para uma caravana rumo a Brasília. No meio disso eu comecei a assumir funções de representação dos trabalhadores junto à administração, principalmente por falta da possibilidade dos trabalhadores que estão dentro da fábrica de estarem o tempo todo em contato com ela. Então, na verdade, eu acompanhava e supervisionava a administração e fui sempre acumulando tarefas de organizar lutas fora da fábrica, junto com esse trabalho de preparar as coisas aqui dentro e, com a experiência que eu tinha, com estudos que fui fazendo, acabei assumindo tarefas de reorganizar a fábrica do ponto de vista de métodos e formas de trabalho e que, na verdade, poderiam melhorar a vida dos trabalhadores sem alterar a produtividade. $\mathrm{Eu}$, por exemplo, ajudei a preparar a mudança da jornada de trabalho para 40 horas, antes eram 44. Também ajudei a pensar junto com eles formas de otimização da matéria prima, e de varias coisas dentro da fábrica, até que no início desse ano eu passei a estar diretamente na parte administrativa e acabei acumulando essas duas funções; uma função mais administrativa, mesmo, da fábrica, junto com a função de coordenar a parte dos apoios externos, de divulgação da luta, de negociação judiciais. Hoje eu faço a parte administrativa, mas não sozinho,outras pessoas trabalham comigo na área que a gente chama internamente 
de "mobilização", que é a relação com os sindicatos, com os movimentos sociais, com o movimento estudantil...

Beatriz - E no ambiente de trabalho, como são suas relações pessoais com os colegas de fábrica?

Pedro - Eu, em particular, não tenho problema com ninguém dentro da fábrica, do ponto de vista das relações de trabalho. O que tem são dificuldades e diferenças que aparecem no cotidiano, tanto no trabalho como na vida, como em qualquer outra fábrica. As brigas pessoais que poderiam afetar as relações no trabalho têm que ser tratadas de maneira profissional, e o conselho de fábrica trabalha nesse sentido. Por mais que a gente tenha uma hierarquia no chão de fábrica, o chefe não manda na estrutura geral de poder, porque você vai ter as assembléias de turno, as assembléias gerais, o conselho de fábrica que se reúne semanalmente e que toma as decisões e que é composto por representantes de cada setor, eleitos pelos próprios trabalhadores. Então, em geral, se encontra um consenso, mas, no limite, a não ser que o cara esteja mandando você fazer uma coisa que coloque em risco a sua vida, você vai ter que cumprir, porque em tese ele sabe mais sobre a questão ${ }^{4}$. No entanto, a pessoa pode chegar ao conselho de fábrica para discutir, explicar, e convencer os membros do conselho que aquele chefe agiu naquele momento errado e então se pode mudar o procedimento. Porque tem que se produzir uma determinada peça, e se você faz um lote mais ou menos azul o produto não é vendido porque não tem uma homogeneidade; agora, ele pode discutir a posteriori, que o produto poderia ser mais daquela cor e que então não daria problema e tal, mas na hora alguém tem que tomar a decisão porque é uma coisa prática para se fazer.

Beatriz - Então, por exemplo, se uma pessoa achar que algo está errado ela pode convocar uma assembléia?

Pedro - Um trabalhador a qualquer hora pode pedir uma assembléia e então a fábrica pára para realizá-la. Mas o procedimento mais normal seria vir aqui falar comigo para convocá-la, inclusive para dar tempo para as pessoas virem. Poderia fazer isso para qualquer coisa, mas é meio que também o bom senso, pois você vai fazer uma assembléia para discutir, sabe, questões que não caberiam, então vai ter que parar a fábrica para reunir trabalhadores de turnos diferentes, vai ter um monte de gente com opiniões diferentes sobre uma questão que, na verdade, requer um tempo muito maior para ser explicado. Então, em geral, a gente trabalha para orientar dessa forma; se há um problema ali em determinado lugar ou setor deve-se conversar com a pessoa responsável diretamente, se não resolver traz-se aqui pro conselho de fábrica, não resolvido a gente leva para a assembléia. Mas se você fizer uma pesquisa ainda hoje, talvez sessenta porcento de sugestões, alterações, mudanças, discordâncias que os trabalhadores têm eles apresentam diretamente ao conselho de fábrica; no passado, em quase todos os casos que alguém achava que tinha alguma coisa errada dentro da fábrica esta pessoa nem falava com o chefe, esperava acabar o turno e vinha aqui falar comigo para reunir o conselho, sabe, para mudar, alterar ou explicar para ele. Mas na verdade não é o melhor procedimento, é o procedimento daquele que ainda está entendendo que é submetido ao chefe dele e que não pode nem opinar, o que não é verdade. Então, essas coisas não têm muito modelo porque depende de cada situação, e acho que isso é meio que da cultura das pessoas que não se altera por meio de uma decisão arbitrária. Talvez possam passar 15 anos que essas coisas não se alteram, porque elas se alteram com as novas pessoas. Se você pegar funcionários novos eles já entram com uma forma diferente de pensar... Tem vezes até que trabalhador fala que aqui deveria ser mais rígido e tal. Então você tem que manter uma hierarquia para organizar o trabalho, a produção, mas que ela não seja imposta pelo medo dos trabalhadores de ficarem desempregados, de serem demitidos, e também que

4 O chefe, no caso, exerce uma função que se assemelha a um "mestre", uma vez que ele é escolhido pelos trabalhadores devido ao seu maior conhecimento técnico sobre o oficio em questão. 
ela não seja a simples aceitação de uma forma de fazer a coisa como ela é dada, mas que ela seja uma compreensão dos trabalhadores que é necessário fazer daquela forma naquele momento, mas que aquilo pode ser alterado a partir da discussão, de estudo de novos procedimentos, de sugestões, que sejam coletivamente debatidas. Na fábrica nós tomamos uma decisão que tiramos depois da intervenção. A gente tem um regimento de contratação e demissão que prevê que a gente não faz demissão pela extinção de posto de trabalho. Por exemplo, se a gente tirar uma determinada função, por exemplo, "não se faz mais bombonas com gravação", numa fábrica normal o setor da gravação seria todo demitido, aqui não, vamos realocar todos eles. Então não tem demissão por esse motivo, não tem a ver com o custo da fábrica. A gente entende que ocupamos a fábrica para salvar empregos, defender os empregos, e não para verificar se a fábrica é viável ou não economicamente, porque isso depende de uma série de fatores que estão fora e não dentro da fábrica. A empresa para ser viável depende de qual é a carga tributária, qual é o preço da matéria prima, que depende do dólar e tal. A gente tem bastante claro que não fazemos demissão por motivo da alta do preço do plástico, ou porque eu comprei uma máquina que trabalha dez vezes mais então não precisa de dez trabalhadores.

\section{"A ocupação da fábrica é a gente assumir a fábrica"}

\section{Beatriz - Você poderia nos falar um pouco sobre a historia da Flaskô?}

Pedro - Nesse terreno antes de ser a Flaskô, na década de 70, era a uma das unidades da Cipla que produzia componente plástico pro setor automobilístico. No final de 70 , começo dos anos 80, passa-se a produzir embalagens, que é o que a gente faz até hoje, e em 1988 ela vira Flaskô. Ela, na verdade, já foi uma das maiores fábricas de embalagens do Brasil, de embalagens plásticas industriais para área de alimentação, setores químicos, fertilizantes e tudo mais. Na época quando ainda era Cipla, a fábrica era grande, tinha uns duzentos trabalhadores; depois, com o crescimento do setor de embalagens, ela alcançou no começo dos anos 90 os seiscentos funcionários. Só que dentro da Flaskô tinha outras unidades fabris, tinha a Brakofix que foi uma fábrica em que os antigos donos da fábrica fecharam em São Bernardo e trouxeram aqui para dentro, tinha a Fiorisa que fazia equipamentos para o lar etc. Só que como todas eram do mesmo dono, ficavam no mesmo prédio, e os funcionários eram contratados, sabe, por uma ou por outra, mas trabalhavam nas mesmas máquinas, trabalhavam na máquina que quando o produto tivesse a caráter iria ser vendido pela Flaskô, e trabalhava na máquina que quando o produto fosse vendido ia ser vendido pela Fiorisa, tudo nesse espaço físico. Por que se fazia dessa forma? Em primeiro por conta da carga tributaria, pois se você tem uma empresa que fatura muito você tem um imposto maior, então o cara monta três ou quatro empresas para diminuir o faturamento de cada uma, mas somando cada uma delas dá o mesmo. A mesma coisa com os funcionários... Mas daí em 1988 que ela se transformou em Flaskô mesmo, começou a crescer, inclusive a gente comprou uma máquina que tem até hoje aqui que é a Malzier, a máquina que faz o tambor, que na verdade na época foi à primeira máquina a fazer esse tipo de tambor no Brasil. A Flaskô chegou a ser, no começo dos anos 90, a mais importante indústria desse setor em todo o país, mas foi exatamente no momento em que o conjunto do grupo econômico dos antigos donos, que envolvia a Cipla, a Interfibra, e outras fábricas que depois também foram ocupadas pelos trabalhadores, entraram numa crise geral. E a forma que os empresários trabalharam para resolver isso, a crise de uma empresa, na época, para você ter uma idéia, eles tinham cerca de 47 empresas, era mandar a dívida de uma empresa para outra, dinheiro de uma para outra para pagar e, na verdade, na somatória, dez anos depois eles acabaram quebrando todas elas. Porque, para entender isso de maneira mais precisa, os mesmos donos da Flaskô eram os 
donos da Cipla, e a Cipla era e é concorrente direto da Tigre, e a Tigre era uma empresa que antes era sócia da Cipla, separaram-se e passaram a ser concorrentes. A Tigre cresceu muito, virou uma gigante, quase uma multinacional brasileira, e a Cipla começou a quebrar. A Cipla fazia outras coisas também, para além de tubos de conexões, vendia produtos para a indústria automobilística. Nessa concorrência a Cipla foi quebrando e a Flaskô que, ao contrário, naquela mesma época não tinha dívida nenhuma e só ia crescendo. Mas o que eles fizeram? Diante de perder com a Cipla, eles passaram a arrancar o dinheiro todo da Flaskô para tapar aquele buraco, mas, na verdade, foi só um tapar o buraco mesmo, não foi uma tentativa administrativa de resolver a questão. Hoje a Flaskô é uma fábrica que acumula 110 milhões de dividas, só de imposto pro estado de São Paulo, aqui na região de Campinas ela está entre as cinqüenta maiores empresas devedoras. Então eles foram saqueando mesmo, e ficando ricos, investindo em outros lugares. Por conta disso a Flaskô começou a entrar em crise por volta de 1994 e depois com a subida do petróleo ela piorou, até que em a partir de 1995 ela entrou numa grande crise, de seiscentos funcionários fomos para duzentos em 1998. A ocupação aqui da Flaskô, quando os trabalhadores decidiram em assembléia não deixar a fábrica fechar e assumir o controle da fábrica para continuar recebendo e mantendo o emprego, tem tudo a ver com essa questão de todas as fábricas serem de um mesmo grupo. $\mathrm{Na}$ Cipla aconteceu a mesma coisa: de cinco mil funcionários chegou a ter oitocentos. E assim vinha se demitindo, os patrões não pagavam mais os salários, pagavam trinta, quarenta reais por semana. Ia fechar a fábrica mais cedo ou mais tarde... Em janeiro de 2002 os trabalhadores fizeram uma greve que foi uma tentativa de manter os salários em dia, mas que foi desorganizada e não se colocou a questão de como efetivamente enfrentar o dono. $\mathrm{O}$ dono foi lá e disse "se a fábrica parar não vai ter salário e demite-se todo mundo" e o pessoal aceitou. Nisso daí demitiram oitenta e continuou igual a como era antes, sem pagar salários e tudo mais. Em outubro de 2002, fruto de uma coisa que é simples para quem quiser entender e difícil para quem não quiser, tinha uma situação particular no Brasil que era a eleição do Lula, uma situação em que o conjunto dos trabalhadores estava com esperança de ver seus problemas resolvidos, estavam apostando que agora alguma coisa iria começar a mudar. $\mathrm{Na}$ Cipla, no primeiro turno das eleições iniciou-se uma greve, sabe, organizada, inclusive com o apoio de vereador do PT de Joinville, pedindo apoio, como é tradição do movimento sindical, pro Lula, que era um ex-sindicalista candidato à presidência na época. Então se tirou uma delegação de trabalhadores para ir até Florianópolis no comício do Lula, pedindo apoio para resolver a questão, mediar com a justiça, tudo o que pudesse ser feito, e Lula prometeu dar uma saída para os trabalhadores.

Beatriz - Antes da ocupação?

Pedro - Antes da ocupação, ainda no meio da greve. Isso foi bastante importante porque os trabalhadores dez meses atrás tinham sofrido uma derrota numa greve e agora faziam uma greve num outro clima, num clima de ter uma solução para o que eles viviam, mesmo que ela não fosse muito objetiva, mas era uma esperança de que... esperança não é uma coisa muito prática, é uma idéia de resolver alguma coisa, de melhorar. E os trabalhadores resolveram logo após esse comício ocupar a fábrica com essa esperança de solução, de achar que a situação de conjunto ia mudar com a eleição do presidente Lula. Fora a greve que durou uma semana, a crise toda, a pressão, o piquete que teve, as manifestações que tiveram em frente à casa do empresário dono da Cipla, a opinião pública que era toda favorável à greve da Cipla, já que ela era a mais antiga indústria de Joinville com mais de 50 anos, então significa que muita gente da cidade tem o pai que trabalhou lá. Então tinha todo o apoio social e o empresário ficou pressionado em não fazer aquilo que ele poderia ter feito, como pegar a tropa de choque e "ó, isso aqui é a minha fábrica, é a minha propriedade e vamos todo mundo para fora", ele poderia ter feito, mas não fez, não porque é bom ou ruim, mas porque o conjunto da situação não permitia ele fazer isso. Assim, os trabalhadores ocuparam a fábrica e a mantiveram. Com isso, o que aconteceu? Aqui, como o dono tomou essa porrada toda porque a Cipla voltou a funcionar sem ele, a Flaskô tava em crise e acabou, na verdade, 
sendo abandonada completamente. Os gerentes viam que lá tinham perdido e abandonaram a Flaskô em dezembro, a ocupação da Cipla tinha sido em novembro. Em janeiro não sobra nenhum gerente e se corta a energia aqui na fábrica. Então só sobrou a parte administrativa em um nível, não vou nem dizer secundário, mas lá embaixo mesmo, nível de auxiliares, e na fábrica os chefes que não eram gerentes, mas líderes operários. E ficou janeiro sem luz, ai em fevereiro ligou com uma liminar, em março a gente começou a fazer campanha da Cipla e organizar os trabalhadores junto com os sindicatos fora da fábrica. Porque mesmo que os gerentes não tivessem aqui dentro da fábrica, os funcionários da área administrativa tinham esperança e achavam que ia se resolver ainda trazendo um novo gerente. Em maio tem uma importante assembléia dos sindicatos dos químicos, que é o sindicato da categoria, porque foi um período em que estávamos preparando a caravana dos trabalhadores da Cipla que ia ser recebida pelo Lula. Fez-se uma reunião dos sindicatos dos químicos para receber a caravana, e resolveram tirar dois representantes da Flaskô para participar dela. Então foram dois representantes para Brasília, e lá o Lula não apresentou de maneira prática nenhuma solução, mas prometeu encontrar uma. Foi criada uma comissão de trabalho envolvendo vários ministérios para encontrar essa solução. Isso, na verdade, era mais um elemento para reforçar que "ó, não veio nenhuma mala de dinheiro, não veio nada que resolvesse imediatamente, mas tamo tocando já há seis meses la na Cipla e na Interfibra e o presidente disse que vai ajudar alguma coisa e não é qualquer presidente". Na volta a gente fez uma assembléia dia 12 de junho ali na porta da Flaskô, hoje nossas assembléias são preparadas aqui dentro, mas essa assembléia foi realizada no portão da fábrica, do lado de fora. Os trabalhadores da Flaskô decidem assumir os controles operacional, financeiro e administrativo, elegeu-se uma comissão, que a gente chamou na época de conselho de fábrica, para fazer a administração, e foi dessa forma que se deu a ocupação, diferente da Cipla onde teve uma greve, teve enfrentamento com piquete, com a polícia tentando dissolvê-lo. Aqui foi pelo próprio abandono dos donos. Quando se fala em ocupar a fábrica tem várias pessoas que acham: "vocês ocuparam a fábrica então vocês estão morando dentro da fábrica", e não tem nada a ver. A ocupação da fábrica é a gente assumir a fábrica. Ocupar uma fábrica não é igual há duzentos anos atrás que você tem um tear, você produz coisa nesse tear, e vende para quem você quiser. Hoje você tem nota fiscal, tem compra, tem venda, tem conta bancária, tem um monte de complicações burocráticas que não são fáceis, o que em geral empurra muita gente para montar cooperativas, associações, um monte de coisa sem entender o que é... Porque eu tenho certeza que a maior parte dos trabalhadores, se forem perguntados se querem trabalhar num lugar onde você tenha direitos ou num lugar que você não tenha FGTS, ele não vai ter dúvida. A cooperativa não tem férias, não tem décimo terceiro... Eu contei isso tudo porque a gente acabou, na verdade, utilizando-se do movimento que aconteceu na Cipla, e isso hoje tem implicações. Por exemplo, a justiça decidiu, a pedido do INSS, fazer a intervenção na Cipla. Isso é uma coisa bastante interessante porque a Cipla tem dívidas desde 1990 com o INSS e essa dívida em particular que o INSS decidiu cobrar é uma dívida de 1998, dos antigos donos, e que poderia ter sido cobrada naquela época. A justiça, através do INSS, decidiu tirar a administração das mãos dos trabalhadores e passou para um administrador oficial, um interventor, que na época quis ganhar a administração daqui da Flaskô de brinde, porque a decisão era fazer a intervenção na Cipla e na Interfibra por um processo contra a Cipla, mas como elas trabalhavam junto, então ele pensou que a Flaskô estava no bolo. Ele tentou vir aqui, mas não tinha legalidade para medida jurídica nenhuma, a gente não aceitou ele entrar, o expulsamos e continuamos funcionando. Só que hoje, por exemplo, não temos conta bancária. Tivemos que abrir uma outra conta bancária e por muito tempo tivemos que funcionar com a conta bancária dos próprios funcionários, o que inclusive do ponto de vista do imposto de renda é uma complicação para cada um. Hoje nós não temos uma autorização judicial que nos permita negociar energia elétrica que está atrasada. Então a gente meio que funciona ainda hoje dessa forma, as pessoas sabem que a gente está aqui há cinco anos, mas do ponto de vista da legalidade não temos nenhum, temos vários pedidos da justiça e vivemos num limbo jurídico. O certo seria quem compra nossas mercadorias pagar para a Flaskô, isso 
significa pagar para uma conta bancaria da Flaskô, mas o que ocorre é que eles pagam numa conta bancaria que é dos trabalhadores. Formalmente a gente está nessa situação, tem a ver com que ocorre na Cipla e tem decorrências importantes. Temos uma dívida que herdamos dos antigos donos e que só mudou de nome, porque quando a gente assumiu a fábrica tinham três contas de energia atrasadas, que acabamos pagando de maneira parcelada, mas, em função da intervenção da Cipla, deixamos essas três contas atrasadas e ficamos 40 dias com a fábrica parada. Hoje a gente tem que negociar, com uma necessidade urgente até 16 de dezembro, com a CPFL, mas não temos legalidade para isso e a CPFL se utiliza disso para falar que "agora eu não vou mais negociar com vocês". Então, para concluir essa parte da historia da Flaskô, na verdade é uma historia que tem a ver com o conjunto das lutas dos trabalhadores no Brasil no período recente, nos últimos cinco anos, que ocuparam as fábricas para tentar manter os seus empregos. A gente, com o nosso tamanho pequeno (chegando a ter 88 funcionários, contando os afastados), mas contando com todo o conjunto das lutas que acontecem em outros lugares, acabamos tendo uma força e uma expressão muito maior do que aparentemente teríamos pelo número de trabalhadores. O Movimento das Fábricas Ocupadas já participou de ocupações vitoriosas e derrotadas, em mais de 40 cidades no Brasil, e às vezes é difícil de entender a repercussão disso na prática, mas tem. Quando você vai ver na hora de negociar com a própria justiça, com a CPFL, esse apoio externo é bastante importante.

Beatriz - Quais os maiores desafios na mudança de uma empresa privada para uma fábrica ocupada?

Pedro - A perspectiva dos trabalhadores antes da fábrica estar ocupada, é que o dono tem que cumprir com que é responsabilidade dele - salários, direitos trabalhistas - e isso faz com que os custo de um trabalhador seja muito caro por conta dos impostos. Os empresários reclamam dos impostos, mas todo mundo sabe que o empresário não paga os impostos sozinho. O empresário coloca os impostos no preço do produto. No período de ocupação é diferente, é um período que os empresários não pagavam e os trabalhadores não tinham também uma perspectiva do que fazer, diante disso. Em geral, essa é uma perspectiva que acontece em todas as fábricas que estão em processo de falência. As fábricas começam a ter dificuldades, os trabalhadores começam a não receber seus salários e tentam fazer um acordo com o dono para ser demitido, essas coisas. Então a situação anterior da ocupação foi um desespero por falta de uma orientação coletiva sobre o que fazer não deixar a fábrica fechar e as pessoas perderem seus empregos. E aí que tem a importância do sindicato, do partido, das associações, em constituir essa orientação coletiva. Foi o que a gente fez aqui na Flaskô, sabíamos que a fábrica era viável, mas que tinha sido prejudicada por uma série de fatores da época do dono. Isso foi um elemento que permitiu aos trabalhadores lutarem por seus empregos de uma maneira coletiva, ocupando a fábrica. Mas a discussão em seguida, que tem a ver com os desafios que enfrentamos, que embora hoje nós administramos a fábrica, não temos culpa das dívidas herdadas anteriormente à ocupação, e também não somos responsáveis pela política econômica do país. $O$ banco não faz empréstimos para trabalhadores de uma fábrica ocupada, eles fazem empréstimo para grandes empresas. Dessa maneira, foi-se deparando que se os trabalhadores não tiverem se organizando, discutindo uma política nacional para indústria, para economia, não tem como manter em longo prazo a fábrica funcionando. Acho que o maior desafio nosso acaba não sendo um desafio interno. $O$ desafio maior é de como construir uma forma de ter uma política efetiva que permita que fábricas administradas pelos trabalhadores, fábricas ocupadas, possam continuar funcionando, porque do contrário em um projeto político nacional, nossas multinacionais concorrentes a qualquer momento podem nos levar a falência, elas tem esse poder. Cada solução milagrosa que a gente inventa aqui dentro para melhorar, para manter a fábrica aberta, a gente sabe que é jogar o problema para frente, que mais cedo ou mais tarde a gente pode tropeçar no nosso cadarço, porque não tem como controlarmos esses outros aspectos políticoeconômicos. 
Beatriz - Na minha primeira visita à fábrica ${ }^{5}$ você tinha falado sobre certas especificidades da Flaskô que permitem que hoje ela esteja funcionando. Você poderia comentar esses aspectos?

Pedro - É isso daí é uma coisa bem importante. No estado de São Paulo, a única que produz um tipo de tambor como o nosso - com um anel em volta, com filtro e com válvulas - somos nós. Tem fábricas que fazem tambores, mas não iguais aos que se faz com a Malzier, que não é só o nome da máquina, mas é a patente da peça, ou seja, a maneira como é feita, a qualidade e a resistência da peça. Hoje no Brasil existem duas Malzier que tem a patente para vender a própria dona e a gente, que comprou a patente. A Flaskô detém quinze porcento do mercado, é uma empresa que tem toda a capacidade para estar funcionando justamente por isso. Tem empresários do setor de plástico que estão montando fábricas parecidas com a nossa, já que tem um crescimento econômico nessa área, eles tão vindo para a Flaskô para comprar os nossos produtos para serem revendidos. Devido a nossa dificuldade de conseguir matéria-prima, esses empresários querem terceirizar nossa mão de obra, sabe, sub-contratar, porque não se tem essa produção em outro lugar. Então você tem algo em potencial que faz com que os trabalhadores entendam que a fábrica é viável e, mais que isso, faz com que os empresários tenham os "olhos grandes" aqui dentro.

\section{"Cada tijolo é resultado do suor de trabalhadores"}

Beatriz - Na reportagem da Veja ${ }^{6}$ eles acusam os dirigentes de usarem o "dinheiro das empresas ocupadas em proveito próprio". O que você tem a comentar a respeito?

Pedro - O juiz pediu para o interventor da Cipla, fazer uma analise dos últimos dez anos da fábrica, dos cinco anos sob a administração dos trabalhadores e cinco anos sob a administração do patrão. No período de administração do patrão, a Cipla estava em concordata e essa concordata, por coincidência ou não, quem fazia era o mesmo interventor. Nesse relatório que ele apresenta ele só faz a analise dos últimos cinco anos, da época que ele era concordatário ele não fez. O que ele chama de proveito próprio são gastos com passagens e a instalação de um sistema de segurança na casa do Serge ${ }^{7}$. Ele está divulgando gastos com passagem aérea para militantes do Movimento dos Trabalhadores Rurais Sem Terra (MST). É a mesma coisa que você questionar um empresário que pagou passagem para um outro numa viagem a negócios. Acho que a questão é que o autor da reportagem é contra pagar passagem para pessoas ligadas ao MST. Sobre o sistema de segurança, isso é verdade, a denuncia aí dele não é mentira, a Cipla pagou um sistema de segurança para a casa do Serge Goulart. Isso foi uma decisão da comissão dos trabalhadores apresentados em todas as assembléias. Mas o porquê a reportagem não diz. Duas semanas antes da intervenção na Cipla invadiram duas vezes a fábrica: eles roubaram um monte de documentos, roubaram o caixa eletrônico, que depois foi encontrado com todo o dinheiro dentro. Também fizeram três invasões na casa do Serge, que tem filho. A discussão na família dele era para ele não ir mais trabalhar lá, já que tinham invadido três vezes a casa deles procurando documentos. Assim, foi feita uma discussão na Cipla que o Serge ia sair e foi proposto, para ele não sair, que iria tomar medidas de segurança, se cogitou inclusive contratar segurança para ficar na porta da casa dele, foi uma decisão conjunta, entre todos os trabalhadores. A mesma coisa um dono de uma empresa que está ameaçado de seqüestro e a empresa precisa pagar pela segurança dele.

5 Visitei a Flaskô em setembro de 2007, aproximadamente dois meses antes da realização da presente entrevista.

6 Reportagem da revista Veja, intitulada "Ocupar e arruinar - radicais do PT criam o MST das fábricas e usam o dinheiro das empresas ocupadas em proveito próprio”. Edição 2023, 29 de agosto de 2007.

7 Serge Goulart era na época da ocupação da Cipla coordenador administrativo da fábrica. 
$\mathrm{Eu}$, recentemente, se você procurar na internet, fui ameaçado varias vezes, inclusive há poucos dias atrás. Você vai dizer que isso é pessoal? Eu acho que tanto o Serge como eu se não tivesse um compromisso com isso aqui, preferiríamos trabalhar em outro lugar e não sermos ameaçados. Sabe, ninguém ta aqui ficando rico aqui. $\mathrm{Na}$ verdade, são acusações em que não se contam toda a historia, apenas as partes que são convenientes.

Beatriz - Você poderia comentar também sobre o quadro "O que acontece em uma fábrica ocupada", que aparece ao final da reportagem? ${ }^{8}$

Pedro - Bom, sobre a contratação de funcionários, em que eles falam que os principais cargos executivos são ocupados por militantes do Movimento das Fábricas Ocupadas, vários cargos sim, mas não todos. Na administração da Cipla, nenhum dos cargos executivo era composto por militantes, tanto que esse pessoal da administração permanece até hoje dentro da fábrica porque eles se aliaram ao interventor. As aulas sobre revolução russa eu gostaria que todos estudassem, isso sem dúvida alguma. Tem aula, a gente estuda, até menos do que acho que deveria ser, mas de forma alguma é algo compulsório. O que houve, e imagino que é daí que a reportagem distorce, foi a redução da jornada de trabalho de 40 horas para 30 que conseguiram fazer na Cipla. A discussão é que nesse período que o trabalhador estava livre, colocamos atividades dentro da fábrica como aulas de economia, da revolução russa, de ioga - intitulado como "artes marciais" na reportagem. A redução da jornada de trabalho é para melhorar a qualidade de vida dos trabalhadores, um tempo para ficar com a família, para eles estudarem e não para arranjarem um segundo emprego. Vários trabalhadores arranjaram um segundo emprego, mas a discussão que fazemos é que eles não deveriam ter. Em primeiro lugar, para não pegar emprego de outro e, em segundo, porque nessas horas eles deveriam terminar o supletivo, estudar, fazer atividades etc. Mas não é nada obrigatório, talvez fosse até melhor.

Beatriz - Essa redução da jornada de trabalho foi sem perda salarial?

Pedro - Sem perda salarial e mantendo a mesma produtividade da fábrica. É interessante você ver que hoje eles retornaram para 44 horas e a fábrica continua faturando a mesma coisa. Os trabalhadores, como estão trabalhando hoje estão sem a mínima motivação. Quanto à questão da demissão, existe uma luta aqui: ou você está junto com a luta ou você não está. Em relação ao dinheiro utilizado para campanhas políticas e para dar boa vida para os dirigentes partidários ou aliados como o MST, só posso dizer que ganho quase dois mil por mês e trabalho mais que quinze horas por dia. Nesse outro ponto ocorre uma mesma distorção. Todos os trabalhadores são estimulados a ir em todas as greves, a todas as campanhas, a luta dos estudantes, e são liberados do trabalho para ir. A gente acha que isso aí é fundamental, sem isso não vamos nunca poder mudar a política econômica do Brasil. Agora intimidados e obrigados? Pode até ser que trabalhadores se sintam intimidados, mas aí é outra coisa. A gente chega na assembléia e explica que a Flaskô tem 110 milhões de dividas e para continuar funcionando precisa haver ajuda do governo para uma mudança na situação econômica. Intimidar alguém é explicar a situação política e econômica da fábrica? Agora o que ele está chamando de preocupação com a rentabilidade certamente é demitir os trabalhadores que são muitos custosos, como já fez o interventor da Cipla demitindo 250 trabalhadores, dentre esses trabalhadores aposentados. Se isso é preocupação com a rentabilidade nós não temos mesmo. Mas na Cipla o faturamento teve um salto de 900 mil, sob a administração do dono, para 4 milhões, sob a administração dos trabalhadores. A

8 Esse quadro é composto de várias características que segundo a reportagem ocorre em uma fábrica ocupada pelos trabalhadores. Essas características seriam: 1) "Os principais cargos executivos são ocupados por militantes do movimento Fábricas Ocupadas, ligado ao PT"; 2) "Aulas sobre a Revolução Russa são compulsórias e os funcionários precisam ler os livros indicados"; 3) "Quem não comparece nas assembléias ou faz oposição é demitido"; 4) "Funcionários são dispensados do trabalho para distribuir panfletos e CDs de políticos aliados"; 5) "O dinheiro ganho pela empresa é utilizado para campanhas políticas e para dar boa vida aos dirigentes partidários ou aliados, como o MST"; 6) "Não há nenhuma preocupação com a rentabilidade da fábrica"; 7) "São produzidos cassetetes dentro da fábrica para enfrentar a polícia. Há treinamento de artes marciais". O entrevistado vai comentando essas características, com exceção da quarta, na ordem acima. 
Flaskô faturava 50 mil e chegou a faturar, antes da intervenção, até um milhão de reais. Antes de explicar o que ele realmente está dizendo, nesse último ponto do quadro, eu queria deixar claro que eu não seria contra produzir cassetetes. Se tivéssemos feito como os grandes empresários que possuem uma segurança armada, talvez tivesse sido diferente do que aconteceu na Cipla9. A polícia e os jagunços dos fazendeiros se armam contra os trabalhadores, então por principio eu não sou contra. Ensinar arte marcial, qual é o problema? Aqui mostra um nível de "fascistização" dessa discussão da Veja. Qual o problema de trabalhadores fazerem arte marcial?

Beatriz - Queria retomar uma ultima coisa sobre a reportagem da Veja, fazendo uma ligação sobre a proposta de estatização da Flaskô. Eu cito: "O objetivo da comissão era salvar a empresa e os empregos, mas o que se seguiu foi pura politicagem", diz o presidente do sindicato, que rompeu com a administração esquerdista da fábrica em fevereiro de 2003. A meta imediata do Movimento das Fábricas Ocupadas é a estatização das empresas sob administração dos funcionários. "Nós queremos ser trabalhadores como os da Petrobras e do Banco do Brasil disse a Veja Serge Goulart, líder máximo do movimento e, durante o período de ocupação, coordenador administrativo da Cipla". Queria, se possível, que você comentasse sobre duas coisas: a questão da estatização e a relação da Flaskô com o Movimento das Fábricas Ocupadas.

Pedro - A questão da estatização a gente poderia discutir longamente, mas eu estou sem tempo, então vou tentar ser breve. Primeiro em relação ao Movimento das Fábricas Ocupadas, é um movimento que surgiu junto com a ocupação da Cipla que tem como instrução a questão de que os trabalhadores não podem aceitar que o capitalismo, os empresários, fechem as fábricas e os utilizem como "laranjas", descartando quando os convém, destruindo tanto os empregos quanto o próprio parque fabril brasileiro. Você chega em São Paulo vendo vários galpões fechados e que, na verdade, cada tijolo é resultado do suor de trabalhadores que um dia fizeram isso e está sendo jogado ao lixo. A estatização, por outro lado, é a forma como a gente desde o começo viu que deveria pensar em uma solução duradoura, mesmo que possam ter várias soluções provisórias como a ocupação da fábrica para manter nossos empregos. A gente entende que a solução duradoura é a estatização no sentido de uma política econômica alinhada de acordo com os interesses gerais da sociedade. A estatização tem a ver em não colocar os trabalhadores como donos de uma empresa, fábrica, ou mesmo de uma cooperativa, porque, se eles querem manter seus empregos, têm que se colocar como objetivo tirar a economia dos interesses dos empresários e colocar aos interesses dos próprios trabalhadores. E a Cipla é prova disso, que mesmo só com uma solução provisória que era ocupar a fábrica, sem a estatização, nós mostramos lá que podemos quintuplicar o faturamento da fábrica, reduzir a jornada de trabalho para 30 horas mantendo a mesma produção da fábrica. Se a gente não discutir isso hoje, por mais que pareça um mundo distante, a Flaskô quebra amanhã pela concorrência com grandes empresários. Nas cooperativas mesmo que as pessoas entrem com boas intenções o que acaba acontecendo é que eles viram pequenos empresários que só ficam pensando em como conseguir um financiamento aqui, em reduzir ali, etc. A rentabilidade no mundo de hoje é: ou você tem um banco como seu sócio ou você tem que reduzir os direitos dos trabalhadores.

9 Dia 31 de maio, 150 policiais federais invadiram a Cipla e "empossaram" um interventor nomeado por um juiz federal com base em um pedido feito pelo INSS (Instituto Nacional de Seguridade Social). 